somatic substance present in both motile and nonmotile forms. These observations on Proteus were later found to fit in admirably with similar observations made several years previously by Smith and Reagh in the United States on a member of the Salmonella group, and provided the basis of a wide generalization on the antigenic structure of bacteria.

At the end of the First World War, Felix worked for a time at Prague and, after taking a three-months course in tropical medicine at Hamburg, moved in 1920 to Palestine, where he served as a hospital bacteriologist for some years. In spite of his attach. ment to Zionism, he was forced to the conclusion that Palestine could not offer him the opportunities for research that he wanted, and he gladly accepted an offer in 1927 by Prof. J. C. G. Ledingham to join the Lister Institute in London. There he settled down among congenial colleagues and added to his reputation by discovering the $V i$ antigen of the typhoid bacillus. In 1939 he was appointed to a post in the Emergency Public Health Laboratory Service, in which he built up what was later to become the Central Enteric Reference Laboratory and Burcau. His development of the $V i$-phage typing method for 'finger-printing' typhoid bacilli, which had been introduced by Craigie and Yen in 1938, attracted world-wide interest, and in 1947 Felix's laboratory at Colindale was designated the international reference laboratory for the phage-typing of these organisms. Felix retired from the Public Health Laboratory Service in 1954, and returned to the Lister Institute where, with a research grant, he was able to tidy up some of his unfinished work.

Dr. Felix married in 1923 Leah Gluckman, of Tel-Aviv, who survives him.

G. S. WIISON

\section{Prof. James Small}

Prof. James Small died on November 28 at the age of sixty-six. Born at Brechin, Forfarshire, he was educated at Brechin High School, the Pharma. ceutical Society's School, and Birkbeck College (University of London). After graduation he lectured for a brief period at Armstrong (now King's) College, University of Durham, and then at the outbreak of the First World War joined the Black Watch Regiment. $\mathrm{He}$ was wounded and invalided out of the Army in 1916, and returned after a period of convalescence to his appointment at Armstrong College. In 1916 he became lecturer in botany at Bedford College, University of London, and in the following year was appointed also lecturer at the Pharmaceutical Society. He left London in 1920 to take the chair of botany in The Queen's University, Belfast, succeeding Prof. R. H. Yapp. He was elected to the membership of the Royal Irish Academy in 1922, and to the fellowship of the Royal Society of Edinburgh in 1926. He held the chair at Bolfast until his retirement in 1954, when the Senate of the University bestowed the title of emeritus professor upon him.

Small's first major research was on the Compositae. His work on this family was published as a New Phytologist monograph in 1919 under the title "The Origin and Development of the Compositae", and for this research he received the degree of D.Sc. of the University of London. In 1922, Small contributed a chapter to J. C. Willis's book, "Age and Area", on the evolution of the Compositae, and this initiated a series of papers in which he joined Willis in rejecting natural selection as an explanation of the course of evolution, advocating instead the idea of a sudden origin of species. He drew evidence for this from several groups, plant and animal, but particularly from the diatoms and Foraminifera, which have fossil records suitable for quantitative analysis. Rocondite in style, these studies on "quantitative evolution" have seemed to some almost perversely out of step with current evolutionary thought; yet by his intensive analysis, Small brought to light quite remarkable regularities in the evolutionary history of the groups that came under his attention, regularities which remain to be explained by any evolutionary theory claiming to have general validity.

His other main line of research concerned $p \mathrm{H}$ phenomena in plants. $\mathrm{He}$ devised a colorimetrical method for the determination of $p \mathrm{H}$ in plant tissues in the early nineteen-twenties, and the results of numerous observations were brought together in the Protoplasma monograph "Hydrogen-ion Concentration in Plant Cells and Tissues" in 1929. His book, " $p \mathrm{H}$ and Plants", was published in 1947, and another of a more general nature, entitled "Modern Aspects of $p \mathrm{H}^{\prime}$, in 1953. In this year also he wrote a contribution on "The $p H$ of Plant Cells" to the current series of Protoplasmatologia monographs, and during his final illness he completed the correction of the proofs of a contribution on the estimation of $p H$ values in living tissues and saps to Paech and Tracey's "Modern Methods of Plant Analysis".

His work on $p \mathrm{H}$ led. Small to an interest in stomatal mechanisms, on which he published several papers. He was also actively concerned with the problems of protoplasmic movement, and devised a technique for its study in living stems. His important observation of very high rates of cyclosis in living sieve-tube elements of marrow is often overlooked, despite its high significance in relation to solute translocation.

Small's many-sided work on evolution and plant physiology was recognized in 1951 by the award of the Makdougall-Brisbane Prize of the Royal Society of Edinburgh, for distinguished research published in the journals of the Society.

His early interest in pharmacognosy was responsible largely for the writing of Small's "Textbook of Botany" (first edition, 1921 ; fourth edition, 1937), which was intended principally for the use of medical and pharmaceutical students, and which in its encyclopadic nature reflected its author's own vast acquaintance with morphological botany.

For practically a quarter of a century Small was a member of the committee of the British Pharmacopœia, and he served on the council of the Pharmaceutical Society of Northern Ireland from its inception. He wrote innumerable papers on the botanical char. acteristies of officinal plants, and contributed a long series of beautifully illustrated articles to the journal Food on the structure, properties and uses of drugs and spices.

From 1920, when winning a vest-pocket camera in a newspaper competition provided an introduction, Small had an enthusiastic interest in photography, both technical and artistic. He became keenly aware of the potentialities of photography for recording the structures of botanical objects in the magnification range $\times 1-20$, and his superb pictures taken with the Small-Watson camera have been widely published and exhibited. This activity gained him election to the fellowship of the Royal Photographic 
Society in 1938-an honour which he treasured as highly as any that came to him in the more academic sphere.

A great lover of argument, Small never failed to stimulate through his perennial heterodoxy, coupled with his impressive width of botanical knowledge. To those who knew him well he was the most kindly and generous of men, full of a humour which was wont to find its expression at times in the gertle teasing of authority, more particularly authority which was itself humourless.

$\mathrm{He}_{\theta}$ is survived by his wife, two sons and daughter. J. HesLop Hatrison

\section{Prof. D. R. Boyd}

David Runciman Boyd, who died on December 28, gave forty-one years service to university education in Southampton, and was one of the ablest of a very small and steadfast band whose work has made the University of Southampton possible. Born on February 26, 1872, he was the son of the minister of the parish of Mains, near Dundee. His father died when he was only one year old, leaving a widow and three young children in straitened circumstances. The family moved to Edinburgh, and young David attended the then rather spartan John Watson Institution during 1880-86. After a short period on the classical side of George Watson's College, he moved to Glasgow and in 1888 entered the University of Glasgow. He had a distinguished undergraduate career, gaining prizes in chemistry, natural philosophy and mathematics, and in 1892 was awarded the B.Sc. degree with honours in chemistry. With the Robert Donaldson scholarship he studied in Victor Meyer's laboratory at Heidelberg, acting as Jacobson's assistant for a year, and gained the Ph.D. degree. After about two years as demonstrator in chemistry, under Frankland, at the Mason College, Birmingham, he was one of five lecturers appointed in 1896 to the Hartley Institution, Southampton, with the object of bringing the teaching up to university standard. This was so far successful that the Institution became the Hartley University College, with a small and precarious Treasury grant, in 1902. It was largely due to Boyd and his colleague, John Eustice, head of the Engineering Department during 1892-1931, that the College survived the frequent crises of the first decade of this century.

Up to 1919, Boyd never had more than one academic assistant, and the major part of a heavy teaching programme fell on him. He was an excep. tionally clear and inspiring teacher: Prof. C. K. Ingold, a student at the College during 191I-13, writes: "he treated us to a most exciting exposition of the whole of Chemistry as a living, growing subject, rich in opportunity for the questing spirit. Werner's resolution of cobaltammines, and Knorr's and Kurt Meyer's work on ethyl acetoacetate came hot from the Annalen or Berichte, yet without sacrifice to the pattern of the lecture course as a whole. Everything was critically (and remarkably soundly) assessed, and some much publicized but unsound work dealt with severely". After 1920, with a somewhat larger staff, though still small by university standards, the teaching was maintained throughout at a very high level until his retirement in 1937.

Until about 1930, Boyd kept research going actively, despite very meagre resources. His name appears on some twenty papers, and another ten by his pupils are on lines initiated by him. He studied various aspects of the chemistry of aromatic compounds, and a series of papers on organic compounds of phosphorus is of particular interest. Two papers on the kinetics of reaction between sodium derivatives of phenols and ethylene oxides are still frequently quoted. He encouraged several other successful lines of research, in different branches of chemistry, in his department. He was awarded the D.Sc. degree of the University of Glasgow in 1902, and frequently examined for that University.

Boyd was invaluable in the administration of the College, in which he took a large part. He was chairman, later dean, of the Faculty of Science for many years, and vice-principal after the retirement of Prof. Eustice in 1931. He was tall, gentle and dignified, with courtly manners; he spoke and wrote clearly and persuasively, and spoke so little of himself that many of his colleagues were unaware that, over several years while holding the chair, he read for the Bar and qualified as a barrister of the Inner Temple. His unvarying maintenance of high academic standards, unselfishness and outstanding integrity earned the confidence of his colleagues; and he was much loved and respected in his own department. He married in 1909, and had two sons; but his later years were saddened by the death of both his sons in 1944 on war service, and his wife died last August. What the University of Southampton owes to him cannot be over-estimated; and he rendered notable services to chemistry both through his own researches and by the inspiration and sound training he gave to many generations of pupils, whose collective contributions to research and to teaching are an imposing monument to their teacher.

N. K. Adam

\section{Prof. P. N. Chirvinsky}

Petr Nikolaevich Chirvinsky was born on February 7,1880 , in Moscow in a family of a scientific worker. In 1902 he graduated from the University of Kiev. In 1909 he was appointed professor of applied geology in the Don Polytechnical Institute at Novocherkassk and finally in 1943 he became professor of petrology in the University of Molotov (formerly Perm). He died on June 21, 1955.

A petrologist and mineralogist by profession, Chirvinsky took all allied sciences as his province. In his fifty-three years of academic life, it is estimated that he published 380 papers and books comprising 6,760 printed pages, and covering such varied subjects as petrology, mineralogy, crystallography, meteoritics, geology, hydrogeology, astronomy, physics, chemistry and geochemistry. Of these the first four were his main preoccupation, and he has to his credit many published descriptions of igneous, metamorphic and sedimentary rocks, minerals and meteorites. $\mathrm{He}$ was particularly interested in the mineral composition of granites and other igneous rocks, and in this connexion he elaborated a method of "geometrical-chemical" analysis (1937) and published a book on the average composition of rock. forming minerals (1953). Another interest was the chemical composition and genesis of minerals, and one of his papers on a uranium mineral was published in English (Miner. Mag., 20, 287 ; 1925). More than eighty papers and notes were devoted to meteorites. He was also very much alive to the wider problems of cosmology and geochemistry. He was a modest and friendly man, and an excellent and inspiring t eacher.
S. I. TOMKEIEFF 